\title{
Food Security of the Pregnant Population Cared for in Bosques De María in Barranquilla, Colombia in 2020
}

\section{Paula Andrea Castro Prieto ( $\square$ paula.castro@fsfb.org.co)}

Fundacion Santa Fe de Bogotá: Fundacion Santa Fe de Bogota https://orcid.org/0000-0003-1333-7983

Paola Rueda Guevara

Fundacion Santa Fe de Bogotá: Fundacion Santa Fe de Bogota

\section{Omaira Valencia}

Fundacion Santa Fe de Bogotá: Fundacion Santa Fe de Bogota

\section{Research article}

Keywords: Food Security, Pregnancy, Diet, Food, and Nutrition.

Posted Date: October 11th, 2021

DOI: https://doi.org/10.21203/rs.3.rs-944684/v1

License: (c) (i) This work is licensed under a Creative Commons Attribution 4.0 International License. Read Full License 


\section{Abstract}

Background: According to observations of maternal and child health and nutritional indicators and the levels of food insecurity in the Atlantic region, the need to characterize the components of food access, intake and nutritional status of the population of interest in the city of Barranquilla was identified. The aim of this research was to characterize the food and nutritional security of the pregnant population served in Camino Bosques de María Health Service in Barranquilla during their last trimester in 2020.

Methods: This was a cross-sectional descriptive study that assessed the dimensions of food security situation to determine the approximation of access to food, consumption practices, health knowledge, and nutritional status of pregnant women who were cared for by the Camino Bosques de Maria Health Service, located in southwestern Barranquilla, one of the most vulnerable zones in the city.

Results: With regard to household members, information was collected from 331 households, which consisted of an average of 4.6 members; only $10.1 \%$ of pregnant women were in the contributory scheme, while $54.9 \%$ were in the subsidised scheme, and $35.1 \%$ did not have any type of affiliation. The foods with the highest weekly average reported intake were cereals such as rice and pasta (6.3 days per week). In relation to their nutritional status according to anthropometry, $41.4 \%$ had an adequate body mass index, $23 \%$ were overweight, $19.3 \%$ were underweight, and $13.9 \%$ were obese for gestational age. A total of $2.4 \%$ did not have gestational age information for this calculation.

Conclusions: Improving food security and nutrition during pregnancy is vitally important, as it promotes maternal and child health. In a territory such as Barranquilla, this characterization allows health decision-makers to link programs that promote not only health at the intrahospital level but also at the community level, as described in resolution 3280 of 2018 , the ten-year public health plan-currently under evaluation and construction-and the ten-year breastfeeding plan.

\section{Background}

According to the Food and Agriculture Organization of the United Nations (FAO), food security comprises economic and physical access, availability and utilization of food, as well as stability over time in three dimensions [1]. Globally, in 2018, 9.2\% of the world's population was reported to be severely food deprived or severely food insecure, with Africa having the highest prevalence, followed by Latin America and Asia with rates of $9.0 \%$ and $7.8 \%$, respectively [2].

In terms of health, food security is directly related to the health and nutritional practices and status of the maternal and child population through the availability and utilization of food. For example, globally, in 2016, the prevalence of anaemia in pregnant women was $40.1 \%$ [3], and in 2017 each day, 830 women died during or after pregnancy and childbirth [4]. Among children, only $41 \%$ of children under six months had been exclusively breastfed [5], and $41.7 \%$ of children under five suffered from anaemia in 2016. In addition, 47 million children under five years of age exhibited wasting, 144 million were stunted, and 38.3 million were overweight or obese [6].

In Colombia, the definition of food security is based on the dimensions proposed by the FAO; however, it emphasizes the timely and permanent consumption of food in regard to quantity, quality and safety by all people as well as the biological use of nutrients [7]. The National Survey of the Nutritional Situation (ENSIN) indicated that $54.2 \%$ of households suffered from food insecurity and $8.5 \%$ suffered from severe food insecurity [8]. Therefore, some nutritional indicators require special attention in public health. For example, maternal mortality in 2018 was 51.0 per 100,000 live births [9], and the prevalence of anaemia among pregnant women was $26.2 \%$. In children, $36.1 \%$ of children under six months were exclusively breastfed; the prevalence of anaemia in children aged six to 59 months was $24.7 \%$; and the rates of stunting, acute malnutrition and overweight in children under four years were $10.8 \%, 1.6 \%$ and $6.4 \%$, respectively.

The Atlantic Region, where the city of Barranquilla is located, presented a food insecurity prevalence of $65 \%$, which is higher than the national average. A similar situation was found regarding the prevalence of anaemia in pregnant women and children between six and 59 months. The Atlantic region exceeds the national prevalence of anaemia in pregnant women and children between six and 59 months by $28.9 \%$ and $25.7 \%$, respectively, and exhibits a low prevalence of exclusive breastfeeding (20.5\%) and stunting (12.1\%) [8].

With regard to the access dimension, using the basic food basket (Canasta Básica de Alimentos - CBA) tool, it is possible to determine a household's access to food, expressed as access to sufficient and adequate quantities to cover the energy and protein needs of the average household of a reference population at minimum cost [10]. In Colombia, iterations of this instrument are available in different territories, such as Sopó in Cundinamarca [11]; Soracá in Boyacá [12]; and San Andrés, Providencia y Santa Catalina [13], Magdalena Medio [14] and Tumaco in Nariño [15]. However, for the Atlantic region, including the city of Barranquilla, this instrument has not yet been used.

By observing maternal and child health and nutritional indicators and the levels of food insecurity in the Atlantic region, the need to build a characterization of the components of access, intake and nutritional status of the population of interest in the city of Barranquilla was identified, especially in the Bosque neighbourhood located in the southeastern part of the city, one of the many socioeconomically vulnerable neighbourhoods of Barranquilla [16]. This constitutes an important contribution to research and decision-making in public policy. In that way, the 
aim of this research was to characterize the food and nutritional security of the pregnant population served by the Camino Bosques de María Health Service in Barranquilla during their last trimester in 2020.

\section{Methods}

\section{Study design}

This was a cross-sectional descriptive study that assessed the dimensions of food security situation to determine the approximation of access to food, consumption practices, health knowledge, and nutritional status of pregnant women who were cared for by the Camino Bosques de Maria Health Service, located in southwestern Barranquilla, one of the most vulnerable zones in the city.

\section{Source of Information for Analysis}

A secondary analysis of the information collected in the first step of the project called "the effectiveness of a public health intervention for the prevention of stunting in the population under one year of age in an urban area of the Special District of Barranquilla" was approved and cofinanced by the Ministerio de Ciencia, Tecnología e Innovación in Colombia.

The sampling frame consisted of surveys performed with pregnant women who attended Camino Bosques de María between October and December 2020, a period impacted by the COVID-19 pandemic. Women voluntarily participated.

The research team, with the support of nutrition and nursing professionals with experience in prenatal care, completed a survey about food, nutrition and health in the context of food security. The survey was modified after a pilot test according to the findings of the test, such as the mother's level of understanding, ease of completion and time efficiency.

The field collection team carried out a weekly data critique to improve the instrument over time. It should be noted that the survey data were collected digitally through an Excel matrix constructed by the research team. Anthropometric measurements were taken with a weighing machine (Seca 876) and stadiometer (Seca 876) using the Frankfort plan. Measurements were repeated three times (for each woman) to ensure the precision and accuracy of the data.

\section{Variables}

Sociodemographic variables included location of residence; type of housing; age of members of household (years); education (last school approved), according to the International Standard Classification of Education [17]; and occupation. Food access was assessed according to food decisions, purchase of food, and purchased food (bought, given away, taken from the shop or self-produced). Food consumption was assessed according to meal times, usual intake, and diary intake. Health and nutritional status were assessed according to health affiliation, which is the subsidised regime intended for vulnerable populations that paid for by the state, and workers who contribute to the health system; prenatal check-up attendance; body mass index (BMI) for gestational age established in the resolution 2465 of 2016 based on the Atalah classification criteria 1997 [18]; micronutrient intakes; knowledge about health and nutrition; and knowledge about the practice of breastfeeding.

\section{Statistical analysis}

A descriptive analysis was carried out for all variables. The data are described according to the means, medians, and ranges.

The statistical package used in the analysis was $\mathrm{R}$.

\section{Ethical considerations}

The study complies with the principles in the Declaration of Helsinki regarding the development of research that involves human participants. All participants agreed to participate. The databases created for the study were anonymized for statistical analysis and reporting of the results and conclusions. The study was authorized by the ethics committee of Fundación Santa Fe de Bogotá (record number CCEI-10734-2019).

\section{Results}

\section{Sociodemographics}

Three hundred thirty-one pregnant women were screened, of whom 25.1\% lived in the Bosque neighbourhood, $16.6 \%$ in the Gardenias neighbourhood, 5.1\% in the Villa Caracas neighbourhood, 4.2\% in the Sourdi neighbourhood, 4.5\% in the Villa San Pablo and/or Florez neighbourhood, and $44.5 \%$ in other neighbourhoods did not reach a frequency of $0.30 \%$.

The types of housing mentioned by respondents were mostly flats and houses ( $48.3 \%$ and $41.7 \%$, respectively). To a lesser extent, rooms in tenements or other types of structures were identified (10.3\%). Additionally, the predominant type of housing was that which was fully paid for 
(57.4\%) and rented or sublet (38.4\%); only $1.5 \%$ said they were paying for their own house, and $2.7 \%$ said they were in pawn, usufruct and/or de facto occupancy $(2.7 \%)$.

With regard to household members, information was collected from 331 households, which consisted of an average of 4.6 members. From these 331 households, sociodemographic information was collected for approximately 1,512 persons, a figure that varied by variable. This variability was because the survey was answered entirely by the pregnant woman, and in some cases, they did not remember all the information about their families.

On average, the age of the respondents was 23.5 years, while the minimum and maximum ages were 13 years and 48 years, respectively. regarding the educational level, $30.6 \%$ of the household members had level 1 education, i.e., primary education, while $24.5 \%$ had level 2 or 3 education, i.e., secondary education. Regarding activity, $34.7 \%$ were found to be working, and when asked about the type of work, $22.1 \%$ reported that they were unqualified employees and $17.2 \%$ reported that they were labourers (Table 1).

It is important to mention that $36.6 \%$ of the families were composed of a migrant population from Venezuela, a country located in northeastern Colombia.

\section{Table 1. Socio-demographic information on households}




\begin{tabular}{|c|c|c|}
\hline Variable & Frequency & Percentage \\
\hline \multicolumn{3}{|l|}{ Neighbourhood of residence } \\
\hline Bosque & 83 & 25.1 \\
\hline Gardenias & 55 & 16.6 \\
\hline Villa Caracas & 17 & 5.1 \\
\hline Sourdi & 14 & 4.2 \\
\hline Villa San Pablo/Villa San Flórez & 15 & 4.5 \\
\hline Others neighbourhood & 147 & $44.5^{\star}$ \\
\hline Total & 331 & 100 \\
\hline \multicolumn{3}{|l|}{ Type of housing } \\
\hline Flat & 159 & 48 \\
\hline House & 138 & 41.7 \\
\hline Rooms & 23 & 7.0 \\
\hline Others type of structure & 10 & 3.0 \\
\hline Other type of housing & 1 & 0.3 \\
\hline Total & 331 & 100 \\
\hline \multicolumn{3}{|l|}{ Sex } \\
\hline Men & 704 & 46.1 \\
\hline Women & 823 & 53.9 \\
\hline Total & $1527 *$ & 100 \\
\hline \multicolumn{3}{|l|}{ Marital Status } \\
\hline Married & 101 & 6.7 \\
\hline Divorced & 21 & 1.4 \\
\hline Single & 664 & 43.7 \\
\hline Unmarried partners & 713 & 47 \\
\hline Widowed & 18 & 1.2 \\
\hline Total & $1517 *$ & 100 \\
\hline \multicolumn{3}{|l|}{ Educational Level } \\
\hline Level 0 & 326 & 22 \\
\hline Level 1 & 454 & 30.6 \\
\hline Level 2 \& 3 & 364 & 24.5 \\
\hline Level 4 \& 5 & 66 & 4.4 \\
\hline Level 6 & 13 & 0.9 \\
\hline No knowledge & 95 & 6.4 \\
\hline No education & 166 & 11.2 \\
\hline Total & $1484^{*}$ & 100 \\
\hline \multicolumn{3}{|l|}{ Occupation } \\
\hline Looking for a job & 57 & 3.8 \\
\hline Student & 322 & 21.3 \\
\hline Unable to work & 2 & 0.1 \\
\hline
\end{tabular}




\begin{tabular}{|c|c|c|}
\hline Home-based occupations & 376 & 24.8 \\
\hline Pensioner & 2 & 0.1 \\
\hline Unemployed & 231 & 15.2 \\
\hline Working & 525 & 34.7 \\
\hline Total & $1515^{\star}$ & 100 \\
\hline \multicolumn{3}{|l|}{ Type of activity } \\
\hline Artisan & 6 & 1.1 \\
\hline Trader & 41 & 7.8 \\
\hline Domestic employee & 23 & 4.4 \\
\hline Unqualified employee & 116 & 22.1 \\
\hline Qualified employee & 25 & 4.8 \\
\hline Day labourer & 16 & 3.1 \\
\hline Military or police & 3 & 0.6 \\
\hline Labourer & 90 & 17.2 \\
\hline Fisherman & 1 & 0.2 \\
\hline Self-employed professional & 6 & 1.1 \\
\hline Transport & 37 & 7.1 \\
\hline Street vendor & 74 & 14.1 \\
\hline Other & 86 & 16.4 \\
\hline Total & $524 *$ & 100 \\
\hline
\end{tabular}

*The totals change according to the answers given by the pregnant women interviewed.

\section{Food access}

The decision to buy food was made by $66.8 \%$ of the pregnant women who responded to the survey. Similarly, $92.1 \%$ of women made the largest proportion of household food purchasing decisions. Of the food purchases, $78.0 \%$ were made by women.

The purchased food (bought, given away, taken from the shop or self-produced) is described in Table 2.

Table 2. Purchased food 


\begin{tabular}{lll} 
Food & Frequency & Percentage \\
\hline Oil & 201 & 60.7 \\
\hline Rice* & 342 & 103.3 \\
\hline Tuna & 49 & 14.8 \\
\hline Oats & 49 & 14.8 \\
\hline Bienestarina** & 33 & 9.9 \\
\hline Coffee & 45 & 13.5 \\
\hline Meat & 264 & 79.7 \\
\hline Fruit & 152 & 45.9 \\
\hline Flour & 310 & 93.6 \\
\hline Eggs & 155 & 46.8 \\
\hline Milk & 129 & 38.9 \\
\hline Legumes & 226 & 68.2 \\
\hline Bread & 58 & 17.5 \\
\hline Potato & 77 & 23.2 \\
\hline Plantain & 69 & 20.8 \\
\hline Spaghettis & 190 & 57.4 \\
\hline Chicken & 218 & 65.8 \\
\hline Cold meats & 43 & 12.9 \\
\hline Vegetables & 188 & 56.7 \\
\hline Offals & 54 & 16.3 \\
\hline Total & 331 & NA* \\
\hline
\end{tabular}

Rice is a food that some families bought and gave away simultaneously.

** It is a pre-cooked food based on a mixture of cereals, legumes and whole milk powder, with vitamins and minerals and essential fatty acids and easy to prepare. It contains amino-chelated micronutrients that improve absorption in the target population and has an adequate balance of essential amino acids. Contains no preservatives or colouring agents [19].

***NA: does not apply

In terms of the frequency of acquisition, $37.6 \%$ of food was acquired daily (especially foods such as rice, meat and eggs), $16.2 \%$ weekly, $23.5 \%$ fortnightly, $19.8 \%$ monthly and $2.9 \%$ every other day or two or three times a week. In turn, the most frequent type of acquisition was purchasing (87.8\%), followed by given as a gift, taken from the shop and bought-given as a gift $(10.6 \%, 1.2 \%$ and $0.4 \%$, respectively). Among the foodstuffs given as gifts were milk, eggs, oil, rice, grains and pasta.

In addition, the most frequent places of purchase were shops (39.7\%), supermarkets (40.9\%) and granaries (12.2\%); only $4.9 \%$ shopped at marketplaces, and $2.3 \%$ indicated places such as greengrocers, minimarkets or street markets. The average monthly amount of money spent on food by households was 99.75 USD (1 COP= 3277).

\section{Food consumption}

For this component, information was collected from 328 pregnant women.

Meal times

A total of $22.2 \%$ of the pregnant women usually ate food before breakfast, $93.9 \%$ usually ate breakfast, $44.8 \%$ had a morning snack, $94.8 \%$ usually ate lunch, $54.2 \%$ had an afternoon snack, $97.8 \%$ ate dinner and only $54.5 \%$ ate food after dinner. 
The foods with the highest weekly average reported intakes were cereals such as rice and pasta (6.3 days per week); sweeteners such as honey, panela and sugar (5.1 days per week); liquid milk (4.1 days per week); and sweets such as candy (4 days per week). In contrast, high-protein foods such as meat, poultry and fish were consumed only 2.5 days per week, 2.3 days per week and 1.6 days per week, respectively, and the consumption of fruit and vegetables did not exceed 3.5 days per week.

\section{Diary intake}

It was identified that fruit in the form of juice (1.9 times a day), sweeteners such as sugar or honey (1.7 times a day), vegetable mixtures (1.7 times a day), sweets such as candies (1.6 times a day) and cereals such as rice or pasta (1.4 times a day) had the highest average daily consumption. However, high-protein foods such as eggs did not exceed the daily frequency of 1.2 times, and beef, veal, chigüiro, rabbit, goat or curi did not exceed the daily frequency of 1.1 times (Table 3).

\section{Table 3. Diary intake}




\begin{tabular}{|c|c|c|c|c|c|c|c|}
\hline Grouping & Food Group / Practice & Minimum & Q1 & Median & Mean & Q3 & Maximum \\
\hline \multirow[t]{2}{*}{ Dairy products } & Milk & 1 & 1 & 1 & 1.3 & 2 & 5 \\
\hline & Cheese, kumis, yogurt, suero costeño & 1 & 1 & 1 & 1.3 & 1 & 5 \\
\hline \multirow[t]{7}{*}{ Proteins } & Eggs & 1 & 1 & 1 & 1.2 & 1 & 3 \\
\hline & Chicken & 1 & 1 & 1 & 1 & 1 & 3 \\
\hline & Beef, veal, chigüiro, rabbit, goat, goat, curí & 1 & 1 & 1 & 1.1 & 1 & 6 \\
\hline & Fish or shrimp & 1 & 1 & 1 & 1.1 & 1 & 3 \\
\hline & Canned tuna or sardines & 1 & 1 & 1 & 1 & 1 & 3 \\
\hline & Chicken giblets & 1 & 1 & 1 & 1.1 & 1 & 3 \\
\hline & Black pudding or offal of beef & 1 & 1 & 1 & 1 & 1 & 3 \\
\hline \multirow[t]{2}{*}{ Vegetal mixtures } & Bienestarina & 1 & 1 & 1 & 1.7 & 2 & 5 \\
\hline & Other plant mixtures & 1 & 1 & 1 & 1.3 & 1.5 & 2 \\
\hline Legumes & Legumes & 1 & 1 & 1 & 1.1 & 1 & 5 \\
\hline \multirow[t]{5}{*}{ Cereals } & Rice or pasta & 1 & 1 & 1 & 1.4 & 2 & 4 \\
\hline & Bread & 1 & 1 & 1 & 1.3 & 1 & 5 \\
\hline & Arepa* & 1 & 1 & 1 & 1.2 & 1 & 3 \\
\hline & Cookies & 1 & 1 & 1 & 1.3 & 2 & 5 \\
\hline & Wholemeal foods & 1 & 1 & 1 & 1.3 & 2 & 5 \\
\hline Potatoes and roots & Potatoes and plantains & 1 & 1 & 1 & 1.2 & 1 & 4 \\
\hline \multirow[t]{2}{*}{ Vegetables } & Cooked vegetables & 1 & 1 & 1 & 1.2 & 1 & 5 \\
\hline & Raw vegetables & 1 & 1 & 2 & 1.1 & 1 & 4 \\
\hline \multirow[t]{2}{*}{ Fruits } & Fruits in juice & 1 & 1 & 1 & 1.9 & 3 & 6 \\
\hline & Fruits & 1 & 1 & 1 & 1.4 & 2 & 5 \\
\hline Fats & Butter, milk cream, lard & 1 & 1 & 1 & 1.1 & 1 & 3 \\
\hline \multirow[t]{3}{*}{ Sugars } & Panela**, sugar, honey or panela & 1 & 1 & 2 & 1.7 & 2 & 4 \\
\hline & Sweets or candies & 1 & 1 & 1 & 1.6 & 2 & 6 \\
\hline & Soft drinks & 1 & 1 & 1 & 1.3 & 1 & 5 \\
\hline \multirow{12}{*}{$\begin{array}{l}\text { Practices of public health } \\
\text { interest }\end{array}$} & Alcohol & 1 & 1 & 1 & 2 & 1 & 6 \\
\hline & Coffee & 1 & 1 & 1 & 1.1 & 1 & 5 \\
\hline & Energy drinks & 1 & 1 & 1 & 1 & 1 & 1 \\
\hline & Fast food & 1 & 1 & 1 & 1 & 1 & 3 \\
\hline & Packaged food & 1 & 1 & 1 & 1.2 & 1 & 5 \\
\hline & Low-calorie foods & 1 & 1 & 1 & 1 & 1 & 1 \\
\hline & Fried food & 1 & 1 & 1 & 1.2 & 1 & 3 \\
\hline & Food prepared on the grill, charcoal or wood fire & 1 & 1 & 1 & 1 & 1 & 3 \\
\hline & Salt shaker & 1 & 1 & 1 & 1.6 & 2 & 3 \\
\hline & Meals prepared at home to eat at work & 1 & 1 & 1 & 1.4 & 1 & 5 \\
\hline & Food away from home & 1 & 1 & 1 & 1 & 1 & 2 \\
\hline & $\begin{array}{l}\text { Eating while watching television, computer or } \\
\text { screen }\end{array}$ & 0 & 1 & 2 & 2 & 3 & 5 \\
\hline Total & & 328 & $N A^{*}$ & & & & \\
\hline
\end{tabular}


* Type of food made of ground maize

${ }^{\star *}$ Is an unrefined whole cane sugar, typical of Latin America

Health and nutritional status

For this component, information was collected from 328 pregnant women.

Health affiliation

Only $10.1 \%$ of pregnant women were in the contributory scheme, while $54.9 \%$ were in the subsidised scheme. Similarly, $35.1 \%$ did not have any type of affiliation at the time of the survey.

Attendance at prenatal check-ups

A total of $66.5 \%$ of participants reported attending. Of the $33.5 \%$ who did not report attending, the reasons were as follows: $0.6 \%$ reported lack of time, $0.6 \%$ reported costly service, $0.6 \%$ reported poor quality service, $0.6 \%$ reported non-compliance, $4.0 \%$ reported too much paperwork, $1.1 \%$ reported not knowing the point of care, $18.9 \%$ reported delays in appointments, $1.1 \%$ reported delays in care, $1.7 \%$ reported not knowing they were entitled, and $4.3 \%$ reported other reasons such as not being affiliated and change of residence.

\section{Nutritional status}

Regarding the distribution by trimester, $29.6 \%$ were in the first trimester, $58.9 \%$ were in the second trimester, $9.0 \%$ were in the last trimester and $2.4 \%$ did not report the information. A total of $57.6 \%$ of the pregnant women reported knowing their prepregnancy weight. Regarding nutritional status assessed by anthropometry, it was found that $41.4 \%$ had an adequate BMI for gestational age, $23 \%$ were overweight for gestational age, $19.3 \%$ were underweight for gestational age, $13.9 \%$ were obese for gestational age and $2.4 \%$ did not have a gestational age for this calculation.

\section{Micronutrient intakes}

A total of $67.4 \%$ of the pregnant women indicated that they were prescribed iron, $54.4 \%$ were given iron, and $61.3 \%$ consumed iron. A total of $66.9 \%$ of the pregnant women mentioned that they were prescribed calcium, $53 \%$ were given calcium, and $61.8 \%$ consumed calcium. Seventytwo percent of the pregnant women reported that they were prescribed folic acid, $57.7 \%$ were given folic acid and $68 \%$ consumed folic acid.

knowledge about health and nutrition.

Awareness of warning signs showed that pregnant women most frequently recognized headache and discharge of fluid or blood from the vagina (31.4\% and $28.7 \%$, respectively). Pregnant women also reported other signs to a lesser extent, e.g., $11.9 \%$ swelling of the face and feet in the morning, $11.6 \%$ wheezing, $10.4 \%$ contractions, and $8.2 \%$ seeing lights.

In terms of knowledge about the practice of breastfeeding, $98.2 \%$ of the respondents considered breastfeeding their babies. A total of $53.3 \%$ of pregnant women were recommended to breastfeed exclusively for an average of 6.3 months, and $40.1 \%$ were recommended to breastfeed continuously with the introduction of food for an average of 15 months.

\section{Discussion}

This study shows that food security is an important component in the analysis of maternal and child health and nutrition. Regarding access to food, it was found that the decision to purchase food was predominantly made by women. In terms of food purchased by households in the month prior to the survey, oil, rice, spaghetti and high-protein foods such as meat and eggs were most frequently reported. However, regarding the frequency of food consumption in pregnant women, the consumption of meat and eggs only reached a frequency of 1.2 times a day. With regard to the nutritional status of the pregnant women, $36.9 \%$ were overweight, and $19.3 \%$ were underweight. Micronutrient prescription did not exceed $72 \%$, and intake did not exceed $68 \%$. Similarly, knowledge of warning signs in general did not exceed $18.4 \%$, with the exception of headache and vaginal discharge, which reached $31.4 \%$ and $28.7 \%$, respectively. Finally, knowledge of breastfeeding practices was scarce.

Recent evidence shows that food purchasing decisions in households are made by women. One of the results obtained in this research shows that $92.1 \%$ of women make the decision to purchase food to be included in the family food basket; in Soracá Boyacá, a similar level was reported (82.11\%) [20]. Different studies support the fact that women fulfil the role of housewives, which empowers them to make decisions regarding household nutrition [21, 22, 23]. Looking at the food purchased by households, it is evident that is the foods chosen are mostly calorie-dense, while access to healthy food is limited. Similar situations have been observed in other territories, such as San Andrés and Magdalena Medio, where the priority of households has been to access food sources of carbohydrates and sugars $[13,14]$. 
In terms of food intake, two key aspects were identified, the first related to meal times and the second to the source of food consumed on a daily basis. Regarding the first aspect, slightly less than $55 \%$ of participants reported eating snacks between main meals, which is not in line with the Colombian dietary guidelines (Guías Alimentarias Basadas en Alimentos, in Spanish) that recommend three snacks between main meals, i.e., one in the morning, one in the afternoon and one in the evening. This situation is similar to that evidenced in the Survey of nutritional status in Colombia ENSIN 2015, which shows that the daily frequency of meal times in pregnant women is lower for intermediate meal times such as snacks and night snacks; the Atlantic region is the one with the lowest number of meal times per day compared to other regions (8). The second aspect indicates that there is a preference for fruit juices instead of whole fruits (1.9 vs. 1.4 times a day); a high intake of sugars and sweets was also reported (1.7 times a day), contrary to the GABA suggestion, which recommends the intake of whole fruits, encourages limited consumption of sugars and encourages the consumption of water [24].

In relation to micronutrient intake, low prescription rates were identified. These prescription levels are not in line with the Ministry of Health's recommendation and its provision for the first prenatal consultation before 10 weeks, including the prescription of calcium, iron and folic acid [25]. Previous studies have reported higher prescription levels close to $80 \%$. Similarly, low adherence to micronutrient supplementation was a finding in this study. These findings are in line with the literature, which reports an inadequate intake of folic acid [26]. In addition to folic acid, studies also link calcium and iron with low intake adherence among pregnant women $(<50 \%)$ [27]. Similarly, other studies also report moderate intakes of the three recommended micronutrients in pregnancy [28].

The nutritional status of the pregnant women showed a high prevalence of both extremes of malnutrition. The results show that the rate of overweight (overweight and obesity) in pregnant women was $36.9 \%$, while almost one in five pregnant women was underweight for gestational age. In contrast, the results of ENSIN 2015 show that the rate of overweight in pregnant women was 40\% in 2015, while that of underweight for gestational age was found to be $14.2 \%$ [8]. Research on the nutritional status of pregnant women in Colombia reported similar figures of underweight and overweight: $18.6 \%$ and $32.6 \%$, respectively [29].

In terms of warning signs, there was a low level of knowledge among pregnant women, with similar or lower figures than those described in other studies. For example, in Mexico, a study reported $22.1 \%$ for headache and $22.8 \%$ for vaginal bleeding [30], while in Peru, a study reported that more than $80 \%$ of pregnant women indicated vaginal bleeding as a warning sign [31]. In relation to breastfeeding knowledge, the intention to breastfeed was high; however, knowledge was low, as reported in the literature informing prenatal education strategies [32]. A systematic review on food education in pregnant women led to the conclusion that successful experiences stimulate the inclusion of education in prenatal care, with personalized nutritional counselling and the use of ICTs being the alternatives of choice [33]. The results showed an improvement in the level of knowledge achieved; among the learning activities used to achieve the observed changes were the use of individual sessions or small groups $[34,35,36]$, the use of video debate, the preparation of recipes and the delivery of brochures and shopping cards [37, 38]. These findings revealed favourable results for improving the level of knowledge, stimulating changes in dietary patterns and preventing deficiencies through supplementation.

It should be noted that these results were obtained from a population reporting 65\% food insecurity in 2015 (Atlantic region), which may have been further exacerbated by the emergence of the COVID-19/SARS-CoV-2 pandemic.

\section{Limitations}

The sampling for this study did not allow us extrapolate the results to the entire population of Barranquilla because it refers a specific population.

\section{Conclusion}

Strengthening food security during pregnancy is vitally important, as it promotes maternal and child health. Food security not only involves the consumption of healthy foods but also relates to strategies to improve access to healthy foods and prenatal education strategies that promote appropriate practices, knowledge and attitudes in pregnant women and their support network. In a territory such as Barranquilla, this characterization allows health decision-makers to link programs that promote not only health at the intrahospital level but also at the community level, as described in resolution 3280 of 2018 [25], the ten-year public health plan (currently under evaluation and construction) [39] and the tenyear breastfeeding plan [40].

\section{Abbreviations}

FAO: Food and Agriculture Organization of the United Nations; ENSIN: National Survey of the Nutritional Situation (Encuesta Nacional de la Situación Nutricional); CBA: basic food basket (Canasta Básica de Alimentos); BMI: body mass index; ICBF: Colombian Institute of Family Welfare (Instituto Colombiano de Bienestar Familiar); ICBF: Colombian Institute of Family Welfare (Instituto Colombiano de Bienestar Familiar); GABA: Food guidelines (Guías Alimentarias basadas en Alimentos para mujeres gestantes, madres en período de lactancia y niños y niñas menores de 2 años para Colombia). 


\section{Declarations}

\section{Ethics approval and consent to participate}

The study was authorized by the ethics committee of Fundación Santa Fe de Bogotá (record number CCEl-10734-2019). All participants agreed to participate.

\section{Consent for publication}

Not applicable

\section{Availability of data and materials}

The datasets used and/or analysed in the current study are available from the corresponding author on reasonable request.

\section{Competing interests}

The authors declare that they have no competing interests.

\section{Funding}

The study was funded by Ministerio de Ciencia, Tecnología e Innovación de Colombia and Fundación Santa Fe de Bogotá.

\section{Authors' contributions}

We declare that the three authors are responsible and guarantee that all the aspects that make up the manuscript have been reviewed and discussed with the maximum precision and integrity. PCP led the design, interpretation of data, conception, construction, and writing of the final revision of the article. PRG was involved in the construction, conception, and final revision of the manuscript. OV was involved in the construction, information support and final document revision. All authors have read and approved the manuscript.

\section{Acknowledgements}

We thank the community of Camino Bosques de María (Health Service), local associations, local government (Health Secretary), and Mi Red Health Care Service. We also thank the field team including Diana Orozco (Nurse) and Zulay Jimenez (Nutritionist).

\section{References}

1. FAO. Una introducción a los conceptos básicos de la seguridad alimentaria; 2011. Retreived from: http://www.fao.org/3/al936s/al936s00.pdf

2. FAO, FIDA, Unicef, PMA, OMS. La seguridad alimentaria y nutrición en el mundo; 2019. Retreived from: http://www.fao.org/3/ca5162es/ca5162es.pdf.

3. The World Bank. Prevalence of anemia among pregnant women (\%); 2016. Retreived from: https://data.worldbank.org/indicator/sh.prg.anem.

4. WHO. Maternal mortality; 2019. Retreived from: https://www.who.int/news-room/fact-sheets/detail/maternal-mortality.

5. Unicef, WHO. Global breastfeeding scorecard; 2018. Retreived from: https://www.who.int/nutrition/publications/infantfeeding/global-bfscorecard-2018.pdf? ua=1\#: :text=BREASTFEEDING\%20RATES\&text=41\%25\%20of\%20infants\%20less\%20than,breastfeeding\%20rates\%20drop\%20to\%2045\%25.

6. OMS. Malnutrition; 2021. Retreived from: https://www.who.int/news-room/fact-sheets/detail/malnutrition.

7. DNP. Conpes 113 de 2208.; 2008. Retreived from: https://siteal.iiep.unesco.org/sites/default/files/sit_accion_files/co_0442.pdf.

8. ICBF, INS, Universidad Nacional de Colombia. Encuesta Nacional de la Situación Nutricional 2015 Bogotá; 2019.

9. Ministerio de Salud y Protección Social. Análisis de Situación en Salud Colombia; 2019. Retreived from: https://www.minsalud.gov.co/salud/publica/epidemiologia/Paginas/analisis-de-situacion-de-salud-.aspx.

10. Menchú MT, Osegueda OT. La canasta básica de alimentos en Centroamérica, revisión de la metodología, Guatemala. INCAP ME/105. 2002.

11. Alcaldía Municipal de Sopó. Canasta alimentaria básica de Sopó. Sopó: Alcaldía Municipal de Sopó, Cundinamarca; 2015.

12. Trujillo Ramírez, K.M. Situación alimentaria y nutricional en el municipio de Soracá, Boyacá, y su posible asociación con la prevalencia de diabetes y obesidad. Informe de investigación. Bogotá; 2018.

13. Universidad Nacional de Colombia - Sede Caribe. Canasta Básica de Alimentos de la población del Departamento Archipiélago de San Andrés, Providencia y Santa Catalina. San Andrés isla: Universidad Nacional de Colombia, San Andrés, Providencia y Santa Catalina; 2005. 
14. Del Castillo S, Fonseca Z, Mantilla M, Mendieta N. Estudio para la medición de seguridad alimentaria y nutricional en el Magdalena Medio Colombiano. Caso Cesar. Revista de la Facultad de Medicina. 2012; 60(1):13-27.

15. Cardozo Á, Mendoza F, Del Castillo S, González N. Determinación de la canasta usual de alimentos del área rural del municipio de Tumaco. Tesis de Pregrado. Bogotá: Universidad Nacional de Colombia, Nariño; 2014.

16. Cepeda EL. Documentos de economía regional: Los Sures de Barranquilla: la distribución espacial de la pobreza; 2011 Retreived from: https://www.banrep.gov.co/sites/default/files/publicaciones/archivos/DTSER-142.pdf.

17. eurostat Statistics Explained. International Standard Classification of Education (ISCED); 2020 [cited 2021 Agosto 09. Available from: https://ec.europa.eu/eurostat/statistics-explained/index.php?

title=International_Standard_Classification_of_Education_(ISCED)\#Implementation_of_ISCED_2011_.28levels_of_education.29.

18. Ministerio de Salud y Protección Social. Resolución 2465 de 2016; 2016. Retreived from: https://www.minsalud.gov.co/Normatividad_Nuevo/Resolucion\%202465\%20de\%202016.pdf.

19. ICBF. Bienestarina; 2020 Retreived from: https://www.icbf.gov.co/bienestarina-mas-r-0.

20. Castro Prieto, P.A. Brechas de género en consumo de alimentos y estado nutricional en niños, jóvenes y adultos en Soracá-Boyacá, Colombia en 2016. Tesis de Maestría. Universidad de los Andes; 2018.

21. Sandoval QS, Camarena QD. Consumo de alimentos de la población sonorense: tradición versus internacionalización. Estud Soc. 2012:5372.

22. Cunningham KPG, Menon P, Ruel M, kadiyala S, Uauy R, Ferguson E. Women's empowerment in agriculture and child nutritional status in rural Nepal. Public Health Nutr. 2015; 18(17):3134-45. https://doi.org/10.1017/S1368980015000683.

23. Heckert J, Olney D, Ruel M. Is women's empowerment a pathway to improving child nutrition outcomes in a nutrition-sensitive agriculture program? Evidence from randomized controlled trial in Burkina Faso. Soci Sci Med. 2019; 233:93-102. https://doi.org/10.1016/j.socscimed.2019.05.016

24. FAO, ICBF. Guías alimentarias basadas en alimentos para mujeres gestantes, madres en período de lactancia y niños y niñas menores de 2 años para Colombia. Bogotá: ICBF; 2018. Report No.: 978-958-623-194-7.

25. Ministerio de Salud y Protección Social. Resolución 3280 de 2018; 2018. Retreived from: https://www.minsalud.gov.co/Normatividad_Nuevo/Resoluci\%C3\%B3n\%20No.\%203280\%20de\%2020183280.pdf.

26. Holguín HE, Orozco DJ. Administración de ácido fólico y otros micronutrientes en mujeres embarazadas de Colombia. Rev Panam Salud Publica. 2013; 34(2): p. 99-106.

27. Sharma S, Akhtar F, Singh RK, Mehra S. Dietary Intake across Reproductive Life Stages of Women in India: A Cross-Sectional Survey from 4 Districts of India. J Nutr Metab. 2020; 23. https://doi.org/10.1155/2020/9549214

28. Al Bahhawi T, Doweri AA, Sawadi RM, Awaji MY, Jarad MM, Sulays ZY, et. al. Consumption habits of pregnant women in the Jazan region, Saudi Arabia: a descriptive study. BMC Res Notes. 2018; 11(1):817. https://doi.org/10.1186/s13104-018-3921-5

29. Sarmiento OL, Ramirez A, Kutschbach BS, Pinzón PL, García S, Olarte AC, et. al. Nutrition in Colombian pregnant women. Public Health Nutr. 2012; 15(6): 955-63. https://doi.org/10.1017/S1368980011003399

30. García RJ, Montañez VM. Signos y síntomas de alarma obstétrica. Acerca del conocimiento que tienen las mujeres. Revista Médica del Instituto Mexicano del Seguro Social. 2012; 50(6): 651-657.

31. Ticona RD, Torres BL, Veramendi EL, Zafra TJ. Conocimientos y prácticas sobre signos de alarma de las gestantes atendidas en el Hospital Nacional Docente Madre-Niño San Bartolomé, Lima, Perú. Revista Peruana de Ginecología y Obstetricia. 2014; 60(2): p. 123-130.

32. Suárez CM, Movilla FM, Pita GP, Fernández AB. Breastfeeding knowledge and relation to prevalence. Rev. esc. enferm. $2019 ; 53$. https://doi.org/10.1590/S1980-220X2018004503433

33. Puszko Bárbara SSVNPMBLLL. El impacto de la educación alimentaria nutricional en el embarazo: una revisión de las experiencias de intervención. Rev. chil. nutr. 2017; 44(1).

34. Fallah F, Pourabbas A, Delpisheh A, Veisani Y, Shadnoush M. Effects of nutrition educationon levels of nutritional awareness of pregnant women in Western Iran. Endocrinol Metab. 2013; 11(3):175-8. https://doi.org/10.5812/ijem.9122

35. Moreno C, Rivera TH. Influence of an educational program food on the level knowledge center on the pregnant health Los Granados-Trujillo. Crescendo. 2011; 2(1):55-67.

36. Parra B, Manjarrés L, Gómez A, Alzate D, Jaramillo M. Assessment of nutritional education and iron supplement impact on prevention of pregnancy anemia. Biomédica. 2005; 25:211-9.

37. Gutierrez MA, Treto FM, Wong TG. Use of national educational television in a local project to increase the consumption of antioxidant vitamins among pregnant women. Rev Cubana Obstet Ginecol. 2006; 32(2):1-9.

38. Emmett R, Akkersdyk S, Yeatman H, Meyer B. Expanding awareness of docosahexaenoic acid during pregnancy. Nutrients. 2013; 5(4):1098109. https://doi.org/10.3390/nu5041098 
39. Ministerio de Salud y Protección Social. Plan Decenal de Salud Pública 2012-2021; 2013. Retreived from:https://www.minsalud.gov.co/sites/rid/Lists/BibliotecaDigital/RIDE/VS/ED/PSP/IMP_4feb+ABCminsalud.pdf.

40. Consejería Presidencial para la Niñez y la Adolescencia; Fundación Salutia. Plan Decenal de salud pública 2021-2030 Bogotá; 2020. Retreived from: https://www.camara.gov.co/sites/default/files/2021-05/1202142300733132_00006.pdf. 